\title{
SPREMINJANJE TEMPERATURE ZRAKA IN PADAVIN PO LETNIH ČASIH V LJUBLJANI IN TRSTU V OBDOBJU I85I-2002
}

\author{
Darko Ogrin \\ Dr., Oddelek za geografijo, Filozofska fakulteta Univerze v Ljubljani, \\ Aškerčeva 2, 1000 Ljubljana, Slovenija. \\ e-mail: darko.ogrin@ff.uni-lj.si
}

\begin{abstract}
Izvleček
$\mathrm{V}$ prispevku avtor analizira spremenljivost sezonskih temperatur in padavin v Ljubljani in Trstu v obdobju 1851-2002, s posebnim ozirom na zadnjih 15 let. Ugotavlja srednjeročne variacije in splošno tendenco. Večjo variabilnost in izrazitejše temperaturne trende ima Ljubljana. Naraščajo zimske in spomladanske temperature, zmanjšuje se jesenska namočenost in zaradi nje tudi letna, vendar se jesenske padavine $\mathrm{v}$ zadnjih 15 letih ponovno krepijo. To $\mathrm{z}$ višjimi temperaturami napoveduje submediteranizacijo podnebja v Ljubljani in izrazitejše mediteranske poteze $\mathrm{v}$ Trstu.
\end{abstract}

Ključne besede: klimatske spremembe, spreminjanje klime v instrumentalnem obdobju, sezonski temperaturni in padavinski trendi, Trst, Ljubljana, Slovenija.

\section{THE CHANGING OF AIR TEMPERATURES AND PRECIPITATION IN LJUBLJANA AND TRIESTE BY SEASONS IN THE I85 I-2002 PERIOD}

\begin{abstract}
The author analyses the changeability of seasonal temperatures and precipitation in Ljubljana and Trieste in the 1851-2002 period, with special reference to the last 15 years. He has established the mid-term variations and the general trend. A greater variability and better expressed temperature trends occur in Ljubljana. Winter and spring temperatures explicitly increase, autumn wetness and annual precipitation amount is decreasing, although autumn precipitation of the last 15 years has increased again. This phenomenon, together with higher temperatures, anticipates the sub-Mediterraneanization of the climate in Ljubljana and more intense Mediterranean features in Trieste.
\end{abstract}

Key words: climatic changes, climatic changes in the instrumental period, seasonal temperature and precipitation trends, Trieste, Ljubljana, Slovenia. 